\title{
The Synod of Dordt (1618-1619) and a theology of religions
}

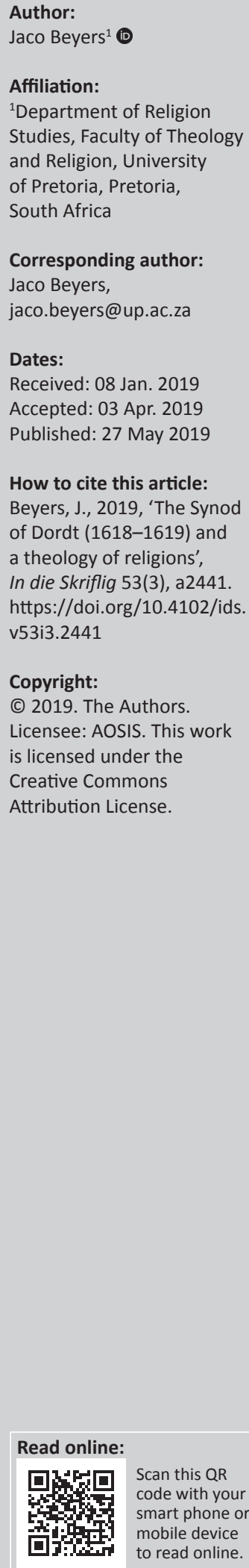

The Synod of Dordt (1618-1619) addressed particular theological concerns raised in a particular context. The broader context of the Synod needs to be accounted for. During the 16th and 18th century, Roman Catholic and Protestant relations in Europe were strained. During the same period, Christianity and Islam were in conflict. Europe was engaging with foreign cultures and religions exposed through a process of geographical discoveries. Within this context the question arises as to how Christianity relates to non-Christian religions. The contribution by the theologian, Gijsbertius Voetius (1589-1676), in creating a theological position on non-Christian religions is paramount in discerning a theology of religions (theologia religionum). The Synod of Dordt and the contribution of Voetius in creating such a theology of religions will here be the focus of the research. Voetius suggests an openness towards non-Christian religions, as all humans are corrupt in nature and in need of redemption. God elects and saves humans from all humankind.

Keywords: Dordt; Missional; Theology of religions; Voetius; Inter-religious relations.

\section{Introduction}

Reflections on inter-religious relations are important today within a multi-religious society. Mass migrations, globalisation and post-colonialism brought communities in contact with different religious backgrounds. The year 2019 sees the celebration of the end of the Synod of Dordt. Is there anything emanating from the deliberations at Dordt (1618-1619) that can contribute to interreligious relations today?

The Synod of Dordt was held from 13 November 1618 until 09 May 1619¹ in Dordrecht, a town in The Netherlands. The purpose of the Synod of the Dutch Reformed Church with invitations extended to eight foreign Reformed churches, was to discuss and decide on the theological doctrine of the Arminians. Among the representatives counted Reformed groups from within Europe as well as from the United Kingdom. ${ }^{2}$ Representatives from the Anglican as well as the Church of Scotland were present. The outcome of the Synod is presented in what is known as The decisions of the Synod of Dort on the five main points of doctrine in dispute in The Netherlands. ${ }^{3}$ The five points referred to comprise of (1) divine election and reprobation; (2) Christ's death and redemption; (3) corrupt human nature; (4) conversion to God; and (5) the perseverance of the saints. These five points are considered to be the cornerstone of Calvinism.

This article wants to address, in particular, the way in which the Synod of Dordt contributed to the formation of a theology of religions and especially the role the Dutch theologian, Gijsbertius Voetius, ${ }^{4}$ played in creating a theological position on non-Christian religions. Theology of religions is concerned with the theological reflection on the meaning and value of other religions (Kärkkäinen 2003:20). The question addressed here is how the Synod of Dordt influenced a theology of religions (theologia religionum) or, phrased differently, what theology of religions can be discerned from the Synod of Dordt. Is there any indication or implication as to how the Synod of Dordt suggests the relation between Christianity and non-Christian religions ought to be viewed? What implication does this theology of religions have for mission work among nonChristians? The contribution by Voetius, as one of the representatives at the Synod of Dordt, gives direction in understanding mission work among non-Christians.

\footnotetext{
1.Although some representatives departed on 09 May 1619, the Synod in fact ended on 29 May after completing all administrative matters.

2.These included 25 representatives from England, the Pallatine, Hessen, Genève, Switzerland, Bremen, Emden, Wetterau and Nasau.

3.Also known as the 'Canons of Dordt'.

4.According to scholarly tradition, Voetius changed his original Dutch name of Gijsbert Voet to the Latin form of Gijsbertius Voetius.
} 


\section{The context of the Synod of Dordt}

Before investigating the role the theologian, Voetius, played in the Synod of Dordt and in establishing a theology of religions, it is important to understand the context within which the mainly ecclesiastical event of the Synod of Dordt occurred. For this, two perspectives (theological and political developments) are important:

\section{Theological developments}

\section{Arminianism}

The Synod of Dordt focussed mainly on the theological controversy which arose due to the theological position taken on by the Leiden professor in theology, Jacobus Arminius (1560-1609), who questioned the teaching of Calvin on several points. Opposing Arminius was his colleague, the theological professor, Franciscus Gomarus (1563-1641), adhering to the belief that God elects people by his grace alone. After Arminius' death, his position was carried forward by his followers now known as the Remonstrants. ${ }^{5}$ The dispute at Dordt, however, must be seen as the culmination of a long ongoing theological and political discussion already present since the Synod of Emden (1571) where the doctrines of the Dutch Reformed Church was established (Van Wyk 2018:3). The Remonstrants had a particular view of the state as being the guardian of the church where the contra-Remonstrants proclaimed the autonomy of the church (Coertzen 2018:2).

Arminius' theological teaching held that humans have a free will and can therefore contribute to salvation: God, by grace, saves humans through Jesus Christ as Redeemer, but considers their faith first. Arminius declares in point 16 of his declaration on Predestination that human faith is 'a force and medium contributing towards salvation' (Bakhuizen van den Brink 1960:279). This theological issue will be expounded on later in this discussion.

\section{Roman Catholic relations}

Upon the Reformation and expansion of Protestantism, Roman Catholics responded with a counter (contra) movement to the Reformation in order to re-affirm Catholic status and revitalise Roman Catholicism. One culmination of the contra-Reformation was the Council of Trent (1545-1563) where Roman Catholic doctrine were re-affirmed. The end of the contra-Reformation most probably occurred during the 17th century (Bakhuizen van den Brink \& Dankbaar 1968:5). ${ }^{6}$

The relations between Protestants and Roman Catholics can, however, not be limited to councils and scholarly debates. On political level, the opposition continued. One year prior to the convention of the Synod of Emden (1571), the states of The Netherlands managed to free itself from Spanish rule.

5.This label is derived from the Dutch concept of a declaration (Remonstrance) opposing an existing statement. In 1610 supporters of the position of Arminius drew up such a declaration and requested the church call out a conference to discuss their points of concern and revise the Catechism (cf. Coertzen 2018:2).

6.Although the Council of Trent took place during the 16th century, the influence and implications of the contra-Reformation was to be felt deep into the 17 th century.
This coincided with the tension between Roman Catholics and Protestants in The Netherlands. The Spanish (Roman Catholic) king laid claim to the lowlands of The Netherlands - today consisting of the so-called Benelux countries (Belgium, The Netherlands and Luxemborg). Opposing Roman Catholic rule, the Dutch organised themselves militarily which resulted in the Eighty Years' War.

Prior to and during the time of the Synod of Dordt, the Roman Catholic Church had a theological position on other religions. The theology of Thomas Aquinas (1225-1274) contributed hugely to the Christian expression of relationship with other religions. His theology became the official theology of the Roman Catholic Church at the time of the contra-Reformation. In his Summa contra gentiles, Aquinas deals with the relationship between the church and the gentiles.

Robert Bellarmine (1542-1621), a respected Roman Catholic theologian, formulated the principles on the church's relationship with non-Christian religions based on Aquinas' propositions (Berkouwer 1968:18-19):

- Any human being may sense God spontaneously, that is, through his or her innate senses and intellect by observing and reflecting on God's creation. The Fall injured this ability, but not completely nor without hope of healing.

- It is God's will that all human beings be saved. Therefore it can be accepted that he would provide ways and means to make it possible. It should be accepted that he would have provided ways and means of membership to those who, through no fault of their own, never heard of Jesus or his church.

- Non-Christian religions have a preliminary legitimacy.

The influence of the theology of Aquinas on the thoughts expressed at the Synod of Dordt cannot be denied (Van Wyk 2018:4). The Remonstrants supported the concept of human free will and contribution through faith to salvation. The contra-Remonstrants emphasised the elective grace of God as the centre of salvation without consideration of faith. Bellarmine seems to consider human knowledge of God as valuable, even if it is defective, inadequate and incomplete. Through human effort God can be known. As will be argued later on, Voetius emphasised that knowledge of God is possible only through conveying and proclaiming the gospel.

\section{Christianity and the Muslim advance}

Besides the multiple encounters between European traders and merchants with Muslims along the trade routes to the East, the Muslim military advance on Eastern Europe was the main concern for Christians during the 16th century. Since the fall of Constantinople in 1453, before the Ottoman Empire, the Muslim advance towards Eastern Europe enhanced the growing concern about the future of Christianity. During the 16th-17th centuries, Europe was constantly under threat of Muslim invasion. Only at the battle of Vienna in 1683, the Muslim advance on Europe was finally halted. 
At the Synod of Dordt the desirability to baptise children of Muslim parents was discussed (Kuyper 1899:416). Voetius also addressed the matter of the baptism of children of nonChristian parents living in the Dutch colonies in the East. Converted and unconverted Muslims ended up settling in The Netherlands and its colonies. How Christians should respond to the presence of Muslims in the colonies would follow from the discussions at Dordt.

Against the backdrop of these theological considerations, the deliberations at the Synod of Dordt must be read.

\section{Political developments}

\section{Relation: State and Church}

The tension in The Netherlands between church and state was apparent with the presence of the 18 representatives of the States-General at the Synod of Dordt. Their task was mainly to see to it that order prevails at the Synod and to ensure that only matters pertaining to ecclesiastical concern were discussed. In reality, the impression was created that the state protected the church, but, in fact, the state controlled the church (Coertzen 2018:3).

The Netherlands, during the last part of the 1500s, experienced political turmoil which international intervention could not even stifle. In this regard, compare the interpretation Coertzen (2018:2) gives of the political conditions preceding the Synod of Dordt. The main concern was the fear of the state that the church, claiming worldly power, would influence state government as was the case with the pope interfering with worldly matters. The church on the other hand, held on to the autonomy of the church as governed by God through his Word (Van Wyk 2018:1). Much of the suspicion around state and church relations had to do with recent tension between Roman Catholics and Protestants in The Netherlands.

Part of the political landscape in The Netherlands was the internal divide between Royalists and Republicans. The Royalists supported the authority of the royal House of Orange as opposed to the supporters of the emerging Dutch Republic. In this sense, the relationship between state and church was even more complicated, as it would imply an answer to the question as to what government?

\section{Spanish and Dutch relations}

The Eighty Years' War (1568-1648) between Spain and The Netherlands marked the culmination of Roman Catholic and Protestant clashes combined with the supremacy of the pope over society. Seventeen provinces, comprising of regions in The Netherlands, Belgium and Luxembourg, revolted against the Spanish rule over The Netherlands. In 1578, with the Union of Utrecht, several Dutch provinces combined power and decided that each province regulate the religious life within the province on condition that religious freedom is maintained (Jongeneel 1991:49). This is significant in terms of permitting and tolerating diverse religious expressions within these Dutch provinces, reflecting a rudimentary theology of religions.

With varying success, the Dutch managed to establish the Republic of the Seven United Netherlands in 1581. The Twelve Years' Truce (1597-1609) ensured temporary peace between the Spanish Crown and the Dutch Republic with a recognition of the autonomy of the Dutch Republic. During the course of 1619, hostilities arose once again, causing the battles to coincide with the Thirty Years' War, ending in 1648 with the Peace of Münster where the Dutch Republic was officially recognised as an independent country.

The battle with Spain resulted in the exportation of war via the Dutch fleet to the various Spanish colonies, increasing the possibilities of Dutch colonial expansion. This increased the exposure to and interaction with non-Christian religions.

\section{Geographical discoveries of the world}

From the 15th century onwards, Europeans engaged in a huge process of expansion. New continents were discovered, foreign cultures were encountered and unknown religions were experienced. New world arenas increased the possibilities of trade leading to an early stage of globalisation. Discovering new minerals and produce - what can be referred to as the commodification of nature - contributed to a drive of colonisation in order to enrich the kings and queens of Europe. The drive by European discoverers eastwards, westwards and southwards removed the veil of mystery from the foreign lands, opening up foreign cultures to European influence as well as opening up Europe to foreign influences.

Representatives, present at the Synod of Dordt, were familiar with the foreign cultures and religions. Islam for one, was the religion of the Turks ${ }^{7}$ or Mohammedans. An overview of the history of Christian mission indicates how mission work during the medieval period saw Roman Catholic as well as Protestant missionaries travelling the globe in order to convert non-believers (compare Neill 1990 [1964]:120-204). Although the accusation is often lodged that mission work was not perceived to be a priority with the early Church Reformers, ${ }^{8}$ the Dutch did launch some efforts to convert non-Christians (Neill 1990 [1964]:190). Mission to the colonies resulted from the colonisation by the Dutch East Company established in 1602. A seminary was set up in Leiden in 1622 in order to train missionaries to serve the spiritual needs of sailors as well as convert inhabitants of colonies (Neill 1990 [1964]:190). A theology of what the relation between Christianity and non-Christian religions ought to be, was necessary.

During the 17th century, Voetius acted as an influential theologian influencing through his participation in the Synod

7.Compare the reference to the religion of Islam as the religion of the Turks in the Canons of Dordt (p. 143).

8.Compare Neill's reference (1990 [1964]:189) to the Roman Catholic, Robert Bellarminus' (1542-1621) accusation that Protestants hardly achieved anything through mission work. 
of Dordt the way in which mission work was done among non-Christian religions in Europe as well as in the colonies. A short excursion as to the person of Voetius may be helpful in understanding his contribution at Dordt.

\section{The contribution of Gijsbertius Voetius}

Gijsbert Voet was born on 03 March 1589 in the town of Heusden close to s'Hertogenbosch in the Dutch province of Brabant (Duker 1897:7). He is the sixth of eight children of which only four survived after birth. Voetius was born during the Spanish assault of Heusden during the Eighty Years' War. He came from an old noble family that used to reside in Germany. The grandfather of his mother, Maria de Jageling (Duker 1897:8), was a leader in a Roman Catholic monastery. His grandfather on his father's side, Paulus Voet, was once the mayor of the town of Heusden. When his grandfather supported the Protestant Reformation he was jailed in Den Bosch. Paulus Voet was a soldier and Protestant. He inherited large pieces of farmland from his brother, but was unable to make a decent living from farming due to the War with Spain and had to support his family with his meagre soldier's pay. Paulus Voet died in 1597 on the battlefield on the outskirts of Heusden (Duker 1897:21).

Voetius was exposed to traditional education in grammar, rhetoric and dialectics. He was from a young age an eager student of Latin and mathematics. After school in 1604, Voetius started his theological training at the University of Leiden with a bursary from his home town (Duker 1897:37). In Leiden, he was exposed to the theological thoughts of Johannes Kuchlinus (the head of the theological school), Bonaventura Vulcanius, Jacobus Arminius, Gomarus and Trelcatius (Duker 1897:40). When Kuchlinus died in 1606 he was succeeded by Peter Bertius as the new head of the theological school (Duker 1897:65).

Gomarus influenced Voetius in terms of Calvinistic theology as well as a love for classic languages (i.e. Hebrew, Greek and Latin). During the last years of his theological training at Leiden, Voetius experienced the theological controversy which culminated in the Synod of Dordt. Arminius started proclaiming his thoughts on predestination which deviated from the mainstream theological ideas. This led to a schism between the supporters of Arminius as opposed to the supporters of Gomarus. After Arminius' death in 1609 his supporters organised themselves within the church in the town of Gouda. Voetius, as part of the Gomarus group, participated in compiling pamphlets opposing the teaching of Arminius. This struggle continued until the Synod of Dordt.

After completion of his theological studies at Leiden, Voetius became the pastor to the congregation at Vlijmen in 1611 (Duker 1897:149). In 1617, he returned to the congregation at Heusden where he performed the duties of pastor for the next 17 years. During this period, he married Deliana van Diest (Duker 1897:154). From the marriage four children survived (Elizabeth, Paulus, Nicolaas and Anna).
Voetius played a significant role at the Synod of Dordt as a representative of the church in the province of Southern Holland. At 30 years of age, Voetius was the youngest representative at Dordt. He was part of the strong opposition of the Arminians and contributes to the discussion on baptism of children of unbelieving parents as well as the discussion on the sinful human nature (Duker 1897:287). Colleagues of Voetius commended his theological knowledge and even considered him to be one of the greatest theologians in Christianity of his time (Duker 1897:290). In 1634, Voetius became professor in Theology and Eastern Studies and Languages at the University of Utrecht (Duker 1897:392). Later in his life, Voetius started studying the Arabic language in order to be able to do effective mission work among Muslims (Duker 1897:373; Nauta 1980:196). It is, however, doubtful whether Voetius did, in fact, converse with Muslims ('the sect of Mohammedans', as he referred to it).

In 1637, Voetius became the pastor of the congregation in Utrecht and in 1642 the rector of the University of Utrecht. This is an illustration of his commitment to serve the faith community in spite of following an academic career. He died in Utrecht on 01 November 1676.

Voetius did not write any complete dogmatics, but left behind a vast collection of writings, letters and pamphlets. His most important works are Selectae Disputationes Theologicae (16481669) and Politica Ecclesiastica (1663-1676). As these works were written in Latin and only later translated into Dutch, the content, until recently, were not accessible to the English speaking academic world (Ireland-Verwoerd n.d.). These works contain his thoughts on mission work. From his letters, the influence of the Scottish reformer, Duns Scotus as well as the thoughts of Augustine and Anselm is apparent.

Voetius always remained a church theologian in spite of being an academic scholar. In one of his letters he emphasised that an ecclesiastical examination besides an academic qualification is necessary prior to be admitted to the service of the church (Nauta 1980:193). His thoughts on mission and relations with non-Christian religions is meant to influence the mission work done by the local congregation.

Although Voetius was since his time as student an avid opposer of the Remonstrant thoughts, he still maintained that a humane treatment of the Remonstrants is necessary. In some communities in Europe, the Remonstrants were vehemently opposed and even persecuted and robbed of their possessions. Voetius was opposed to such actions and demanded that stolen goods in such situations must be returned to the rightful owners (Nauta 1980:200).

Although Voetius held the theology of Calvin in a high regard, he never wanted to be like Calvin (Beck 2011:122). For Voetius, theology did not come from Calvin, but from the Word of God and therefore all believers (even Roman Catholics) are considered catholic in the sense that all Christians share in the interpretation of the Word of God. Voetius wrote several argumentative papers on the ideas of 
Rene Descartes. These conversations with Descartes focussed on the relation between faith and reason. Voetius' biggest contribution to theology must be on the level of mission work. His understanding of the three goals of mission (compare Kritzinger, Meiring \& Saayman 1994 for a complete discussion thereof) still influences theology on mission today (Bosch 1991:257).

The conversion of heathens and the establishment of the church are important actions in mission, but these only contribute to the main goal of mission, namely the glorification of God (see De plantationes ecclesarium in Voetius 1648-1669). With this background in mind, the theological issues, pertaining to a theology of religions, can be investigated.

\section{Theological issues addressed at Dordt and the implications for a theology of religions}

\section{Theological issues}

\section{Corrupt nature of humankind}

Chapter 1, Article 1 of the Canons of Dordt starts out with the statement that, since Adam sinned, the entire human race is in sin and under curse and condemned on account of sin. Chapter 3, Article 1 states that humans brought upon themselves blindness, terrible darkness, futility and distortion of judgement in their minds; perversity, defiance and hardness in their hearts and wills; and, finally, impurity in all their emotions. This corrupt human nature spread through procreation. Children of corrupt humans are corrupt. The corrupt nature causes humans to be unwilling and unable to return to God (Chapter 3, Article 3). All humankind is subject to this total corrupt nature. Salvation can only come from God. All humankind is in need of good news of salvation.

Voetius was confronted with the issue of conveying this good news of salvation to pagans the moment the Synod of Dordt became aware of the request from the classes of Amsterdam of what to do about the request to baptise children of pagans in the Dutch colonies (Jongeneel 1991:48). Jongeneel (1991:48) indicates that Voetius' formulation of an opinion and advice to the Synod of Dordt on this matter, can be considered the first work of Voetius on mission. Voetius' advice was that children, born from Christian and pagan parents - even illegitimate children - are to be baptised only after catechetical instruction and public confession of faith (Jongeneel 1991:48). Faith is thus necessary. Salvation is not universal, although God wants to save all humankind. In this fashion, Voetius provided significant direction in the Synod's decision on baptism of children born to Christian and non-Christian parents.

God's plan to deal with the human condition requiring punishment was to send his Son to the world. Through faith in him, all who believe are saved (Chapter 1, Article 2) and attain eternal life (Chapter 1, Article 4). The way in which this message of salvation reaches the world is by way of God's sending of messengers, ${ }^{9}$ carrying the message of the gospel (Chapter 1, Article 3). Mission work seems to lie at the core of the church and at the decisions taken at Dordt (cf. Van Wyk 2018:10). Salvation comes as a gift of God and is not based on the achievement of humans to believe (Chapter 1, Article 5). This was intended to belie the Arminian claim that human faith is deserving of salvation.

This immediately sets up the foundation for a theology of religions. All humankind are considered to be corrupt in nature and prone to sin. This causes all humankind to be in need of salvation. The salvation, which God, through his grace, provides in Jesus Christ, is directed at all humankind. Those deviating from Christianity are considered as belonging to a false religion (Voetius in Jongeneel 1991:60). It is clear that the Synod of Dordt had in mind the whole human race as those who are in need of salvation and who are able to receive the message of salvation. The Synod of Dordt was therefore, in its deliberation on salvation of humankind, truly inclusive (Van Wyk 2018:6). The message of salvation was not only intended for those who were no longer Christian or the descendants of Christian parents. All humankind ought to hear the message of salvation.

Long after the conclusion of the Synod of Dordt, Voetius would continue in his writings, professing the theological position taken at Dordt when it came to the conveying of the gospel to non-Christians.

\section{Predestination: God elects}

The fact that some people end up believers and some not, is attributed to God's eternal decree where he, before the foundation of the world, elected by grace some to salvation and others not (Chapter 1, Articles 6 and 7). God's election is by grace and not due to deserving humans (Van Wyk 2018:6). God chooses humans who are all lost due to sin. Christ is not the foundation of election, but the foundation of salvation (Van Wyk 2018:6). Election is only in Christ. Salvation is therefore not universal and general to all humankind. Only those belonging to the true religion - Christianity - can claim salvation. Those who believe in Christ, receive salvation in Christ. This results in exclusive salvation in Christ after an inclusive availability of salvation to all humankind.

Humans are not elected because of faith, but faith follows on election by God (Van Wyk 2018:7). It is clear that human choice only follows upon God's choice to elect. Under reprobation (Chapter 1, Article 15), the opposite sequence becomes evident: after humans choose not to believe, God reacts with condemnation and punishment upon unbelief.

Although the main goal was conversion, Voetius considered religious freedom as paramount for peaceful co-existence. His most important writing on religious freedom is De liberate conscientiae et permissione religionum in Republica (Voetius 1643). Voetius (in Jongeneel 1991:49) rejects two extremes and professes one laudable possibility. On the one hand, Voetius 9.Voetius deals with the matter as to whom should be send (cf. Jongeneel 1991:68-71). 
rejects the Roman Catholic position of rejecting all religious freedom, but also on the other hand rejects the unrestrained religious freedom of groups such as Epicurism, Libertinism and Remonstrants. A middle path between the two extremes is possible. For Voetius, no false religion (i.e. Judaism, Islam and paganism) can be defended, but freedom of conscience is permitted and not to be confused with complete freedom of religion (Jongeneel 1991:49). The church does mission work so that all may hear the gospel. Those who God has called and elected will then, upon hearing the gospel, respond in faith and be saved.

Mission, for Voetius, is grounded in God's revealed and hidden will (Jongeneel 1991:56). God wants to save all humankind. God has revealed himself to all humankind, but who will be chosen has not yet been revealed. The mission task of the church is to call and convert the elect - those chosen before time (Jongeneel 1991:56).

\section{Mission task of the church}

Voetius' thoughts on mission is presented in his treatise De gentillismo et vocatione gentium (in 1648-1669). For him God's revealed and hidden will is the basis for mission. God's hidden will determines who will be saved. Mission work is necessary in order to convey to all humanity the message of salvation. Upon hearing the message, those who have been elected by God will get the opportunity to repent, convert and be saved.

Upon conversion people need to become part of the church. The church is the vehicle participating in mission. This is also emphasised by the Canons of Dordt (Chapter 2, Article 8). Jongeneel (1991:65) indicates that Voetius believed this to be a difference between Protestant and Roman Catholic views on mission. Roman Catholic mission theology did not consider conversion as an independent goal of mission work, but as the means to church planting. For Voetius, conversion is necessary in order to enable church planting. Roman Catholic theology considered the presence of the priests as the presence of the church.

In his treatise, entitled De plantationes ecclesarium, Voetius (1648-1669) states that the gospel must be brought to all unbelievers who include heathen, heretics and schismatics. The unbelievers include the uncivilised, the Jews, the Muslims and modern unbelievers. Ireland-Verwoerd (n.d.) comments that, although Voetius mentions several religions by name, he does not include Islam as part of any group of religions. Instead of including Islam as part of the category of heathen religions, he treats Islam as a separate religion worthy to receive the message of salvation. The heathen can be divided into those under Christian government and those under their own heathen government (Ireland-Verwoerd n.d.; Jongeneel 1991:61).

Voetius considers the category of unbelievers to consist of pagans, Jews and Muslims. Jongeneel (1991:60) confirms Ireland-Verwoerd's observation referred to above that Voetius does not consider Islam to be part of the group of pagans, but rather as a separate category. Each of the false religions require a specific way of being addressed and refuted (Jongeneel 1991:60). Non-Christian religions, for Voetius, is a departure from the true religion with paganism as the most gross negligent, and Judaism and Islam less negligent (Jongeneel 1991:60). All those belonging to false religion, however, needs to be converted. As to Jews, Voetius grants Judaism freedom of religious expression and even objects to Christians who want to baptise Jewish children. Jews should be admonished only from the Old Testament, exhibiting some respect for their tradition (Jongeneel 1991:62). Voetius proclaims that besides Jews, also Muslims have maintained some elements of the true religion (Jongeneel 1991:62), exhibiting some form of sympathy with these religions. As monotheistic religions, Judaism and Islam stand next to Christianity. Muslims must be approached with good and holy conduct and reason in order to persuade them to convert to Christianity (Jongeneel 1991:62). Voetius, however, was not sympathetic towards Muslims, as he considered them to still be a false religion, because they replaced Jesus with Mohammed and the Bible with the Qur'an, and denied the trinity (Jongeneel 1991:63). Voetius nevertheless treated Islam and Judaism differently from other religions. This opened the scope as to whom should be considered worthy of hearing the gospel.

\section{Theology of religions}

The Synod of Dordt assisted Voetius in formulating a theology of religions where some religions (as Judaism and Islam) are considered on a different level than mere paganism. Voetius assumed that Jews and Muslims knew something about God and Jesus, and only needed to hear the complete true religion in order to be converted. Pagans had to forget all they knew and learn anew about God and Jesus.

The Canons of Dordt declares that mission is the task of the church to convey the message of the gospel. The gospel should be declared without differentiation and discrimination to all nations and people (Chapter 2, Article 2). All are called (Chapter 3, Article 8) and therefore all should hear the gospel. All humans, whether from a Christian cultural background or from 'heathen' background, are in need to hear the gospel and are supposed to hear the gospel. Stewart (2009:74) is of opinion that Dordt was supportive of the missionary task of the church.

The relation with non-Christian religions was a pressing issue at Dordt. Not only due to the acceptance by Dordt that the gospel ought to be proclaimed to all humankind, but also due to the presence of Jews in The Netherlands (Kuyper 1899:471) as well as the Muslim threat in the East as well as the mission work among non-Christians in the Dutch colonies.

From the discussions and consecutive formulation of the Canons of Dordt, a theology of religions can be deduced and summarised as follows:

- All humans are completely corrupted by sin and in need of redemption. 
- All humans may receive and hear the gospel of salvation in Christ.

- Salvation only happens in Christ.

- Salvation only comes upon redemption, conversion and faith.

- God elected those who will respond with faith.

This theological position corresponds to what D'Costa (1986:80) identifies as the Inclusivist Paradigm and Knitter (2005:150) indicates as the Fulfilment model when it comes to a theology of religions ${ }^{10}$. All humankind is in need of salvation due to sin. God wants to save all humankind. Salvation only comes in Christ. In this way all world religions are able to know something about God, but in order to receive salvation, conversion to Christianity and faith in Christ is necessary. This model is in fact exclusivity in disguise (Knitter 2005:103104). Salvation for all humankind is only possible through faith in Jesus.

The Fulfilment model is a predominant Roman Catholic position on theology of religions (Knitter 2005:63) based on the theology of Karl Rahner as expounded after Vatican II. Rahner follows a long line of arguments reflecting the thoughts of Bellarmine and Thomas Aquinas. The correspondence between Voetius and the Roman Catholic theology of religions, as reflected in the ideas of Bellarmine, is confirmed by Jongeneel (1991:53) when he indicates the Roman Catholic theological influence on the thoughts of Voetius.

Voetius, however, does not fully subscribe to the principles represented in the Fulfilment model as expounded by Rahner. Voetius would, in this sense, rather fall under the category of the Partial Replacement model as identified by Knitter (2005:33). The difference Voetius has with the thoughts reflected in a Fulfilment model is that, whereas humans can have some uncorrupted part of human nature to assist in recognising God and so contribute to salvation through faith in Jesus, Voetius clearly states that salvation is based totally on the salvific grace of God with no human contribution. This was the whole point of the Synod of Dordt to refute the Remonstrants on their theology emphasising human contribution to salvation. Although Jews and Muslims may know $\operatorname{God}^{11}$ (as would be the case in the Fulfilment model), this knowledge of God does not bring salvation (Knitter 2005:33). God, through his elective grace, brings salvation to those who turn in faith to Jesus and him alone. Voetius would then include Jews and Muslims as those worthy of hearing the gospel in order that those among them chosen by God may convert and be saved through faith in Jesus. Their religions need to be replaced by Christianity, but a preliminary knowledge of God is assumed present in their religions.

At Dordt, a statement regarding the freedom of religion was made, if not explicitly then implicitly (Coertzen 2018:4). It is

10.For a complete discussion of models of theology of religions, compare Beyers (2018:1-22)

11.Judaism and Islam recognise God as one; subscribing to monotheism. clear that the Synod could not release the church from the controlling grip of the state. The state, in effect, would also control the freedom of religion. The state would determine which religion would be accepted and which not. Coertzen (2018:4) is of opinion that the Synod of Dordt emphasised the control of the state over religious expressions in society. The state governed and controlled all religious institutions, prescribing religious affiliation and therefore not allowing religious freedom. I am, however, of opinion that the statutes of Dordt did, in theory and theologically, create an openness for non-Christian religions, although, in practice, this freedom was not implemented. Dordt created through emphasising the grace of God an invitation to all humankind to receive the grace of God through Christ. The predestination is not meant to keep people out of the kingdom of God, but rather to emphasise this invitation. Van Wyk (2018:10) is clear in his interpretation that the statutes of Dordt should be interpreted as being inclusive. The predestination is not meant to exclude, but meant to invite to become part of the kingdom of God. In this way, Dordt did contribute to a theology of religions by creating an awareness and openness towards non-Christian religions. Voetius, after the Synod of Dordt completed its work, brought these principles under words in his work on mission.

Stewart (2009:74) supports the statement that the Synod of Dordt was in fact, in spite of accepting divine election, not opposing foreign mission, but 'congenial towards it'. The work by Hoekema (1972) is also in support of how the Synod of Dordt was supportive of missionary work among nonChristians. For Hoekema (1972:217), the interpretation of Article 8 of the Canons of Dordt is crucial to the understanding of mission work. Although missionary eagerness is only implied in this article, according to Hoekema (1972:218), it still urges Christians to convey the gospel to others not because it is the desire of Christians to do this, but because God desires it. Jongeneel (1991:56) emphasises how the interpretation of divine election by Voetius contributed to his understanding of mission work.

\section{Conclusion and implications}

The Synod of Dordt opened up the possibility for the marginalised to enter the scope of God's salvific plan. God elects people from all humankind. Voetius had in mind that the gospel should be brought to all. His own efforts included a plan to present the gospel in the Arab language to Muslims. Although the gospel is conveyed by humans, it is God who elects people in Christ and makes them part of his church.

As confirmed at the Synod of Dordt, all humans are completely corrupted by sin and in need of salvation outside of oneself. Salvation is only possible through the grace of God. God calls humans to faith in Christ. All humans, therefore also those from a non-Christian background, are perceived as sinful based on the total depravity caused by the fall of Adam and Eve. Salvation is only possible in Christ. The message of salvation through Christ is to be brought to 
all humans, as God's grace is intended for all humankind also those who are not yet Christian. Once one has accepted the grace of God in Christ, one becomes part of the Christian community.

Voetius' understanding of mission confirms the need for conversion and being incorporated into a faith community such as the church (cf. Kritzinger et al. 1994:147). This happens in order to glorify God, the only living God. The predestination by God, accepted as confession at Dordt, did not hamper mission work. It, in fact, contributed to the urgency with which Christians and especially the church, ${ }^{12}$ should convey this invitation to all people to join God's kingdom. In this regard, Voetius gave direction to how the church today understands its relationship to non-Christian religions. It is still today the responsibility of the church to convey the gospel message to all people without exception. Theological reflection today will not necessarily, as Voetius did, make the distinction between paganism as gross negligent and Judaism and Islam as less negligent. All religions, and even the context where religion is absent, are worthy of hearing the gospel.

Based on theological arguments presented by Voetius, a theology of religions can be formulated: All religions outside Christianity are false religions. All humankind (Christians included) are sinful and in need of salvation. God has elected who will be saved. The whole humankind (even those from other religions) need to hear the gospel in order for the elect to hear and convert. Jews and Muslims have an advantage over pagans, as they are already familiar with God and Jesus. The church should proclaim the gospel to all.

Voetius studied the Arabic language to encourage mission work among Muslims. He treated Islam as a separate religion and not part of the category pagan religions. He saw God's will to save the elected as universally possible for all humankind. Voetius understood mission as the task to convey the message of salvation to all humankind so that the elected can be saved.

The Synod of Dordt influenced the way in which Christians today reflect on their missionary responsibility. After the Synod of Dordt was concluded, Voetius managed to, on the thoughts expressed at Dordt, compile his thoughts on mission and the relation of Christianity to other religions. Gijsbertius Voetius was instrumental in assisting the church to

12. Compare Voetius' emphasis on the responsibility of the church to be the carrier of the gospel (cf. also Jongeneel 1991:64). understand its task and responsibility of conveying the gospel to all and the relationship of Christianity to nonChristian religions.

\section{Acknowledgements Competing interests}

The author declares that he has no financial or personal relationship(s) which may have inappropriately influenced him in writing this article.

\section{References}

Bakhuizen van den Brink, J.N. (red.), 1960, Documenta reformatoria, Deel 1: Teksten uit de geschiedenis van kerk en theologie in de Nederlanden sedert de Hervorming, J.H. Kok, Kampen.

Bakhuizen van den Brink, J.N. \& Dankbaar, W.F., 1968, Handboek der kerkgeschiedenis, deel 4: De kerk sedert de zeventiende eeuw, Bert Bakker/Daamen, Den Haag.

Berkouwer, G.C., 1968, Nabetrachting op het concilie, J.H. Kok, Kampen.

Beyers, J., 2018, 'A historic overview of the study of theology of religions', in J. Beyers (ed.), Perspectives on the theology of religions, pp. 1-22, AOSIS, Cape Town.

Beck, A., 2011, “'Expositio reverentialis”: Gisbertus Voetius' (1589-1676) relationship with John Calvin', Church History and Religious Culture 91(1\&2), 121-133. https:// doi.org/10.1163/187124111X557809

Bosch, D.J., 1991, Transforming mission: Paradigm shifts in theology of mission, Orbis Books, New York, NY

Coertzen, P., 2018, 'Freedom of religion: From the Church Order of Dordt (1619) to South Africa', In die Skriflig/In Luce Verbi 52(2), 10 pages, a2353. https://doi. org/10.4102/ids.v52i2.2353

D'Costa, G., 1986, Theology and religious pluralism, Basil Blackwell, Oxford/New York.

Duker, A.C., 1897, Gisbertus Voetius, deel 1, E.J. Brill, Leiden.

Hoekema, A.A., 1972, 'The missionary focus of the Canons of Dordt', Calvin Theological Journal 7, 209-220.

Ireland-Verwoerd, F., n.d., Voetius, Gisbertus [Gijsbert Voet] (1589-1676): Dutch reformed theologian and first protestant to write a comprehensive theology of reformed theologian and first protestant to write a comprehensive theology of mission, viewed 27 November 2018, from http://www.bu.edu/miss
missionary-biography/t-u-v/voetius-gisbertus-gijsbert-voet-1589-1676/

Jongeneel, J.A.B., 1991, 'The missiology of Gisbertus Voetius: The first comprehensive protestant theology of missions,' Calvin Theological Journal 26, 56-79.

Kärkkäinen, V.-M., 2003, An introduction to the theology of religions: Biblical, historical and contemporary perspectives, IVP Academic, Downers Grove, IL.

Knitter, P.F., 2005, Introducing theologies of religions, Orbis Books, New York, NY.

Kritzinger, J.J., Meiring, P.G.J. \& Saayman, W.A., 1994, On being witnesses, Orion Publishers, Halfway House.

Kuyper, H.H., 1899, De post-acta of nahandelingen van de nationale synode van Dordrecht in 1618-1619 gehouden: naar den authentieke tekst in het Latijn en Nderlandsch uitgegeven en met toelichtingen vorozien, voorafgegaan door de geschiedenis van de acta, de autographa en de post-acta dier synode ...: een geschiedenis van de acta, de autographa en de post-
historische studie, Höveker \& Wormser, Amsterdam.

Nauta, N., 1980, 'Drie brieven van Gisbertus Voetius', Nederlands Archief voor Kerkgeschiedenis, 60(2), 193-202. https://doi.org/10.1163/002820380X00061

Neill, S., 1990 [1964], A history of Christian missions, Penguin Books, London.

Stewart, K.J., 2009, 'Calvinism and missions: The contested relationship revisited', Themelios 34(1), 63-78.

Van Wyk, B., 2018, 'Die Dordtse Leerreëls: Inklusief of eksklusief?', In die Skriflig 52(2), a2337. https://doi.org/10.4102/ids.v52i2.2337

Voetius, G., 1643, De liberate conscientiae et permissione religionum in Republica, J.H. Kruyt, Amstelodami.

Voetius, G., 1648-1669, Selectae Disputationes Theologicae, 5 vols., Boekencentrum, Zoetemeer.

Voetius, G., 1663-1676, Politica Ecclesiastica, 3 vols., J.H. Kruyt, Amstelodami. 